\title{
MtDNA and nuclear data reveal patterns of low genetic differentiation for the isopods Stenosoma lancifer and Stenosoma acuminatum, with low dispersal ability along the northeast Atlantic coast
}

\author{
RAQUEL XAVIER ${ }^{1,2}$, ANTÓNIO MURIAS SANTOS ${ }^{1,2}$ and MADALENA BRANCO ${ }^{1}$ \\ ${ }^{1}$ CIBIO, Centro de Investigação em Biodiversidade e Recursos Genéticos, Campus Agrário de Vairão, 4485-661 Vairão, \\ Portugal. E-mail: raq.xavier@mail.icav.up.pt \\ ${ }^{2}$ Departamento de Biologia, Faculdade de Ciências da Universidade do Porto, R. Campo Alegre, s/n, \\ 4169-007 Porto, Portugal.
}

\begin{abstract}
SUMMARY: Evidence for a general lack of genetic differentiation of intertidal invertebrate assemblages in the North Atlantic, based on mtDNA sequence variation, has been interpreted as resulting from recent colonization following the Last Glacial Maximum. In the present study, the phylogeographic patterns of one nuclear and one mtDNA gene fragments of two isopods, Stenosoma lancifer (Miers, 1881) and Stenosoma acuminatum Leach, 1814, from the northeast Atlantic were investigated. These organisms have direct development, which makes them poor dispersers, and are therefore expected to maintain signatures of past historical events in their genomes. Lack of genetic structure, significant deviations from neutrality and star-like haplotype networks have been observed for both mtDNA and nuclear markers of S. lancifer, as well as for the mtDNA of $S$. acuminatum. No sequence variation was observed for the nuclear gene fragment of S. acuminatum. These results suggest a scenario of recent colonization and demographic expansion and/or high population connectivity driven by ocean currents and sporadic long-distance dispersal through rafting.
\end{abstract}

Keywords: phylogeography, Stenosoma, direct development, glacial refugia, Pleistocene Glaciations, demographic expansion, connectivity.

RESUMEN: EL ADN MITOCONDRIAL Y NUCLEAR REVELAN PATRONES DE BAJA DIFERENCIACIÓN GENÉTICA EN LA COSTA

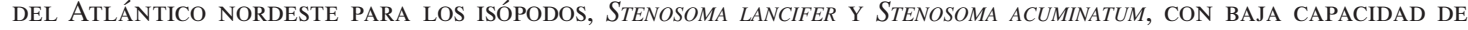
DISPERSIÓN. - LAS evidencias sobre la falta general de diferenciación genética en invertebrados intermareales en el Atlántico Norte, basadas en la variación del ADN mitocondrial, se han interpretado como el resultado de una colonización reciente tras el último máximo glacial del Pleistoceno. En este trabajo se investigan los patrones filogeográficos de un gen nuclear y un gen mitocondrial en dos isópodos, Stenosoma lancifer (Miers, 1881) y Stenosoma acuminatum Leach, 1814, capturados en el Atlántico noroccidental. Estos organismos tienen desarrollo directo y, por lo tanto su potencial de dispersión es limitado, por lo que se espera que sus genomas mantengan señales de acontecimientos históricos. Se ha observado la falta de estructura genética, desviaciones significativas de la neutralidad y redes de haplotipos en forma de estrella para ambos fragmentos de ADN mitocondrial y nuclear de S. lancifer, así como para el ADN mitocondrial de S. acuminatum. En el fragmento del gen nuclear de $S$. acuminatum no se observó variación en las secuencias genómicas. Estos resultados sugieren un escenario de colonización reciente y expansión demográfica y/o de alta conectividad entre poblaciones impulsada por las corrientes oceánicas y la dispersión ocasional a grandes distancias mediante rafting.

Palabras clave: filogeografía, Stenosoma, desarrollo directo, refugio glaciar, glaciaciones del Pleistoceno, expansión demográfica, conectividad. 


\section{INTRODUCTION}

Pleistocenic glaciations are known to have played a major role in shaping the phylogeographic patterns of many organisms, particularly during the Last Glacial Maxima (LGM) (e.g. Hewitt 2004, Maggs et al. 2008). It is generally accepted that in temperate regions, species have had to contract their range into warmer southern areas during glacial periods, whereas during interglacials they were able to re-colonize warming northern areas (Hewitt 1996). These distributional changes resulted in a typical latitudinal gradient of genetic diversity, with higher levels of diversity in southern locations, which served as glacial refugial areas, and with low genetic diversity in the north, where extinctions followed by (re)colonizations have occurred (Taberlet et al. 1998, Hewitt 1999, Luttikhuizen et al. 2008).

For the northeast Atlantic fauna, glacial refugial areas of marine species have been found in the southern regions such as the Macaronesian islands, the Atlantic coasts of North Africa, and the Mediterranean Sea (Coyer et al. 2004, Maggs et al. 2008, Campo et al. 2010, Kettle et al. 2010). However, recent phylogeographic studies have challenged the classical perspective of strictly southern glacial refuges and several studies have uncovered patterns suggesting the existence of glacial refuges for cold-water species in northern areas (Provan and Bennett 2008). These findings showed that the entire northeast Atlantic region has played an important role in the diversification of species, especially in the case of cold-water species. Examples of such refugial areas are located in the northwest of the Iberian Peninsula, in the Bay of Biscay, in the English Channel and even in the North Sea (see for a review Kettle et al. 2010). However, for some species, alternative explanations were advanced for the high allelic richness and levels of divergence observed in some of these locations, particularly in the case of the Brittany and English Channel areas, which are thought to have had dryer or low salinity conditions during the LGM (Ménot et al. 2006). Secondary contact between different re-colonizing lineages originating in southern glacial refuges could also explain the patterns observed in those regions (Coyer et al. 2003, Gómez et al. 2007, Maggs et al. 2008).

A powerful approach to inspect regional patterns associated with either the presence of past glacial refugia or re-colonized areas is to conduct comparative phylogeographic analyses between co-distributed species (Zink 2002). Results from several studies focusing on intertidal species assemblages led several authors to infer that these organisms (especially those with low dispersal ability) were generally more prone to extinction during glacial periods than subtidal species, since the latter could have coped better by migrating to deeper and more stable habitats (Wares and Cunningham 2001, Coyer et al. 2003, Marko 2004, Palero et al. 2008, Rivadeneira et al. 2011).
Species from the genus Stenosoma (Isopoda: Peracarida) are direct-development, brood-caring isopods for which long distance dispersal is thought to be mainly achieved by rafting on floating algae (e.g. Miranda and Thiel 2008). Therefore, their low potential for dispersal makes them a good model to study past vicariance events associated with glacial survival. Previous studies in Stenosoma nadejda (Rezig 1989), which occurs in the Mediterranean and in the Atlantic, where it ranges from the Moroccan coast (Xavier et al. 2011) up to central Portugal (Pereira et al. 2006), showed wellpreserved signatures of a North African vicariance during glacial periods in their mitochondrial genome (Xavier et al. 2011). Stenosoma lancifer (Miers, 1881) and S. acuminatum Leach, 1814 are strictly Atlantic species that find their northernmost distributional limit in southern England (Leach 1814, Miers 1881). While S. acuminatum has never been found south of central Portugal (Pereira et al. 2006), S. lancifer has recently been observed on the Atlantic coast of Morocco. Both species are usually found among intertidal algae (e.g. Arrontes and Anadón 1990a) and seem to have no preference for any type in particular (Pereira et al. 2006).

The aim of the present study was to investigate the phylogeographic patterns of $S$. acuminatum and $S$. lancifer across a south-north gradient along most of their distributional range. Expectations are that glacial refugial areas were likely to occur either in the southern part of their range, as has been hypothesized for the Moroccan populations of S. nadejda (Xavier et al. 2011), or in other putative northern refugial areas such as the northwest of the Iberian Peninsula and the Bay of Biscay (e.g. Kettle et al. 2010). The population genetic patterns expected to be present in glacial refuge areas encompass the existence of high genetic diversity coupled with high genetic differentiation and the prevalence of private haplotypes (Maggs et al. 2008). To accomplish this goal, phylogeographic analyses of one mitochondrial and one nuclear marker were conducted, by examining the DNA sequence variation of the subunit I of the mitochondrial gene cytochrome $\mathrm{c}$ oxidase and of a fragment of the nuclear gene Elongation factor 1- $\alpha$, as both have proved to be useful for detecting population structure in other crustacean species (see Fransen and De Grave 2009).

\section{MATERIALS AND METHODS}

\section{Sample collection, DNA extraction and PCR amplification}

A total of 31 localities were sampled along the distributional range of both species from Wenbury (southern England) to Essaouira (Morroco) (Fig. 1). Sampling was conducted in summer (June-August) and winter (December-February) between 2008 and 2010. Algae were collected during low tide in the lower intertidal zone, where these species are known to occur (Arrontes and Anadón 1990a, 1990b). Because a previous study 


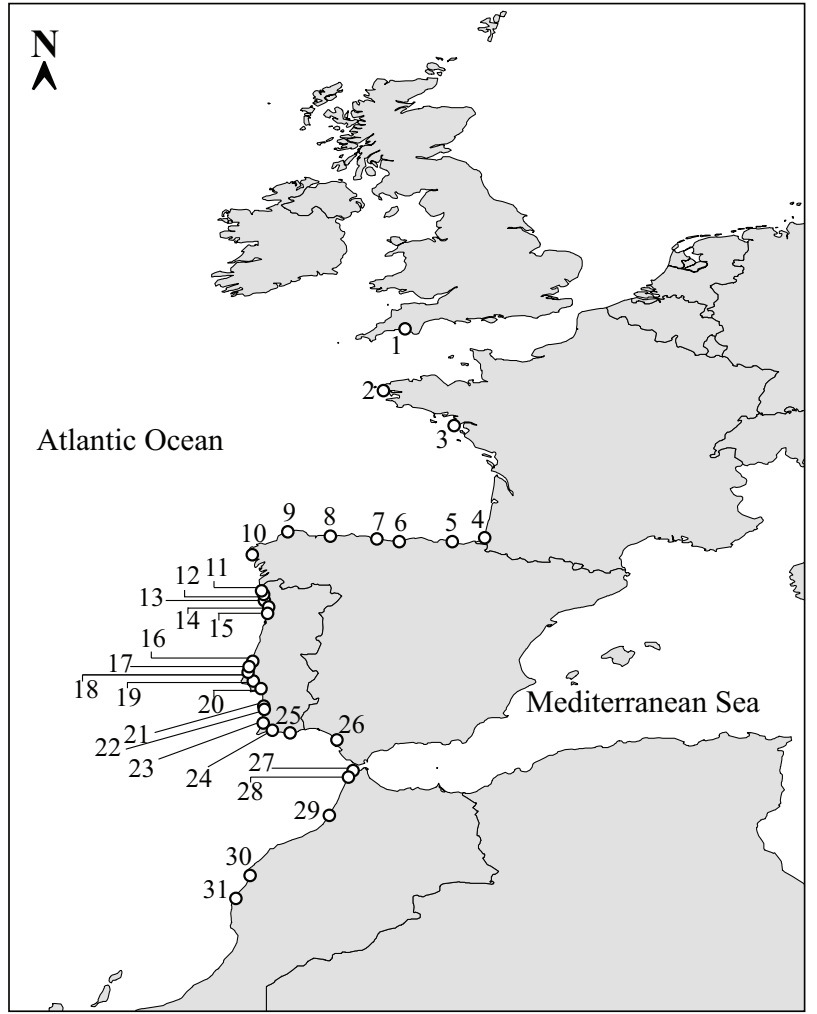

FIG. 1. - Map of sampling localities: 1, Wenbury; 2, Landuvez; 3, Croisic; 4, Biarritz; 5, San Juan de Gastelugatxe; 6, San Vicente de la Barquera; 7, Ribadesella; 8, La Caridad; 9, Espasante; 10, Toriñan; 11, Moledo do Minho; 12, Vila Praia de Âncora; 13, Viana do Castelo; 14, Vila do Conde; 15, Mindelo; 16, Baleal; 17, São Bernardino; 18, Santa Cruz; 19, Praia das Avencas; 20, Portinho da Arrábida; 21, Queimado; 22, Oliveirinha; 23, Castelejo; 24, Porto de Mós; 25, Olhos d’Água; 26, Chipiona; 27, Ksar-es-Seghir; 28 , Cap Malabata; 29, Assilah; 30, Rabat; 31, Essaouira

by Pereira et al. (2006) suggested that neither species shows a preference for a particular type of algae (but see
Arrontes and Anadón 1990a), all algal species present in each locality were collected. Algal material was kept in bags until it was washed with fresh water and Stenosoma specimens were collected. Individuals of S. lancifer and S. acuminatum were identified according to the key provided by Castellanos and Junoy (2005) and preserved in 96\% ethanol. Due to the inconspicuous nature of these species (see Xavier et al. 2009, for a brief discussion on this topic) only 50 individuals of S. lancifer were collected from 11 localities and a total of $26 S$. acuminatum from 6 localities (Table 1, Fig. 1).

Genomic DNA was extracted from legs or from the whole animal when it was too small, using the Jetquick commercial kit (Genomed). A region of the mitochondrial gene subunit I of the cytochrome c oxidase (COI) was amplified as described in Xavier et al. (2009). Several attempts were made to amplify the Elongation factor 1- $\alpha$ gene $(E F 1 \alpha)$ using previously published primers. Successful amplification of a portion of this gene was achieved using EF1AR and EF1AF from the Crandall lab online primer database (http://crandalllab. byu.edu/PrimerDatabase.aspx). Elongation factor 1- $\alpha$ was amplified using the following PCR conditions: initial 4 min denaturation at $94^{\circ} \mathrm{C}$, followed by 30 cycles of $45 \mathrm{sec}$ at $94^{\circ} \mathrm{C}, 45 \mathrm{~s}$ at $55^{\circ} \mathrm{C}$ and $1 \mathrm{~min}$ at $72^{\circ} \mathrm{C}$. Final extension was achieved at $72^{\circ} \mathrm{C}$ for $12 \mathrm{~min}$. PCR reactions were conducted in a volume of $20 \mu \mathrm{l}$ with a magnesium concentration of $3 \mathrm{mM}$. Platinum Taq (Invitrogen, Carlsbad, CA, USA) was used for all PCR amplifications. PCR products were sequenced by a commercial company (High-Throughput Genomics Unit - HTGU, Department of Genome Sciences of the University of Washington). Sequences were checked and edited using CodonCode Aligner (CodonCode, Dedham, MA, USA). The software PHASE v.2.1.1 (Stephens et al. 2001; Stephens and Donnelly 2003; Stephens and Scheet 2005) was used to resolve haplotypes. Command line

TABLE 1. - Estimates of genetic diversity parameters for COI and EF1 $\alpha$ sequence data of S. lancifer and S. acuminatum. N, number of individuals; Nhap, number of haplotypes; Hd, haplotype diversity; $\varpi$, nucleotide diversity.

\begin{tabular}{|c|c|c|c|c|c|c|c|c|c|}
\hline \multirow[b]{2}{*}{ Species } & \multirow[b]{2}{*}{ Locality } & \multicolumn{4}{|c|}{ COI } & \multicolumn{4}{|c|}{$\mathrm{EF} 1 \alpha$} \\
\hline & & $\mathrm{N}$ & Nhap & $\mathrm{Hd}$ & $\pi$ & $\mathrm{N}$ & Nhap & $\mathrm{Hd}$ & $\pi$ \\
\hline \multirow[t]{11}{*}{ S. lancifer } & Biarritz & 11 & 4 & 0.48 & 0.00193 & 2 & 1 & - & - \\
\hline & San Juan de Gastelugatxe & 3 & 1 & - & - & 3 & 3 & - & - \\
\hline & La Caridad & 1 & 1 & - & - & - & - & - & - \\
\hline & Espasante & 2 & 1 & - & - & 2 & 3 & - & - \\
\hline & Touriñan & 4 & 2 & - & - & 3 & 3 & - & - \\
\hline & Viana do Castelo & 9 & 4 & 0.58 & 0.00157 & 1 & 1 & - & \\
\hline & Vila do Conde & 3 & 1 & - & - & 1 & 1 & - & - \\
\hline & Mindelo & 9 & 4 & 0.58 & 0.00160 & 1 & 1 & - & - \\
\hline & Castelejo & 2 & 2 & - & - & - & - & - & - \\
\hline & Rabat & 6 & 3 & 0.60 & 0.00118 & 2 & 3 & - & - \\
\hline & Overall & 50 & 14 & 0.46 & 0.00141 & 15 & 8 & 0.59 & 0.00226 \\
\hline \multirow[t]{7}{*}{ S. acuminatum } & Wenbury & 1 & 1 & - & - & 1 & 1 & - & - \\
\hline & San Juan de Gastelugatxe & 1 & 1 & - & - & 2 & 1 & - & - \\
\hline & La Caridad & 9 & 6 & 0.88 & 0.00271 & 2 & 1 & - & - \\
\hline & Touriñan & 3 & 1 & - & - & 3 & 1 & - & - \\
\hline & Vila doConde & 2 & 2 & - & - & - & - & - & - \\
\hline & Mindelo & 10 & 3 & 0.60 & 0.00130 & 2 & 1 & - & - \\
\hline & Overall & 26 & 10 & 0.71 & 0.00209 & 10 & 1 & 0 & 0 \\
\hline
\end{tabular}


and input files for this software were attained by running SeqPHASE (Flot 2010). Sequences were deposited in GenBank (accession numbers JN652027-JN652125)

\section{Estimates of diversity indices, tests of selective neutrality and recombination}

All sequences were translated into amino acids to confirm the integrity of the sequenced genes and discard the presence of pseudogenes. Estimates of haplotype and nucleotide diversities were calculated for all specimens together and for each sampled locality separately (whenever the number of sampled individuals was more than 4).

To investigate putative selective pressures and demographic history, Tajima's D (Tajima 1989b, a), Fu's Fs (Fu 1997) and Ramos-Onsins and Rozas's R2 (Ramos-Onsins and Rozas 2002) were estimated. In populations in which a recent expansion had occurred, Fu's Fs and Taijima's D are usually large negative values, due to an excess of singletons or recent mutations. Additionally, low values of R2 also indicate a population expansion. To test the statistical significance of D, Fs and R2 estimates, 1000 coalescent simulations were done. Moreover, Harpending's raggedness index $(r)$ (Harpending 1994) was also calculated to test the fit of the data to a population expansion model. This index is calculated under the null hypothesis of population expansion. The minimum number of recombination events (Rm) (Hudson and Kaplan 1985) and linkage disequilibrium ZZ statistic (Rozas et al. 2001) were also estimated for the nuclear dataset. All the aforementioned analyses were conducted using the DNASP software package (Librado and Rozas 2009).

\section{Estimates of population structure and isolation by distance}

Estimates of population differentiation were obtained from pairwise Fst calculations for the mitochondrial dataset, except when the number of individuals sampled was less than four. Significance of pairwise Fst values was tested by performing 300 permutations of haplotypes between locations under the null hypothesis of no differentiation using Arlequin 3.11 (Excoffier $e t$ al. 2005). Spatial genetic structure at the mitochondrial level was further investigated with BAPS 5 (Corander et al. 2004). This software uses Bayesian statistics to test mixture and to define clusters of populations, requiring no a priori knowledge on the geographic structure of populations (Corander et al. 2008). Isolation by distance was tested on the mitochondrial dataset using the non-parametric Mantel test as incorporated in the IBDWS v. 3.15 (Jensen et al. 2005), using Fst genetic and geographical distances (calculated as the approximate linear distance along shoreline) between population pairs and 30000 randomizations. Haplotype networks were obtained using the TCS 1.21 software (Clement et al. 2000).

\section{RESULTS}

\section{Estimates of diversity indices, tests of selective neutrality and recombination}

Alignments for the COI gene included a total of 512 bp for $S$. acuminatum, and 566 bp for S. lancifer. The EF $1 \alpha$ gene fragment comprises an intronic region, which in the case of $S$. lancifer showed considerable size-length polymorphism. To attain more power in the haplotype phase estimates, the intronic region was removed from the final alignment and a 415 bp alignment was produced for 15 individuals of this species, representative of all sampling localities. For S. acuminatum, the EF1 $\alpha$ gene fragment was sequenced for 10 individuals representative of the localities included in the present study. This fragment, including the intron, showed no variation and the final alignment included a total of $905 \mathrm{bp}$. The number of individuals analyzed for the nuclear gene fragment, EF1 $\alpha$, is a subset of that used for the mtDNA due to the difficulties in obtaining good amplicons and respective sequencing data from all sampled individuals.

Only phased haplotypes with a probability of more than $90 \%$ were included in the analysis. For S. lancifer the parameter $\mathrm{Rm}$ was zero and the $\mathrm{ZZ}$ statistic was non-significant, indicating the absence of recombination $(Z Z=0.0031, P>0.05)$. Since there was no variation in nuclear sequences of $S$. acuminatum, recombination parameters were not estimated. Overall estimates and partial estimates (for locations with more than 4 individulas) of haplotype and nucleotide diversity indices for COI and EF1 $\alpha$ are given in Table 1 for both $S$. lancifer and $S$. acuminatum. For the mtDNA gene COI, both haplotype and nucleotide diversity estimated over all sampled individuals were highest for S. acuminatum, with values of 0.708 and 0.00209 , respectively. For $S$. lancifer, these same estimates obtained over all sampled individuals were 0.460 and 0.00141 , respectively. For the nuclear gene EF1 $\alpha$, sequence variation was observed only for S. lancifer and estimates of haplotype and nucleotide diversities obtained over all individuals surveyed were 0.59 and 0.00226 , respectively.

Due to the lack of regional structure (see results given by BAPS), selective neutrality tests were estimated over all sampled individuals. At the mitochondrial level, all tests of selective neutrality were significant $(P=0.05)$ for both $S$. lancifer and $S$. acuminatum (Ta-

TABLE 2. - Results of selective neutrality tests and Harpending's Raggedness index, for COI and EF1 $\alpha$ sequence data of $S$. lancifer and $S$. acuminatum. In the case of $S$. acuminatum lack of variation at the nuclear level prevented the determination of these estimates. * indicates significant values $(P<0.05)$.

\begin{tabular}{lccccc}
\hline Species & Gene & Tajima's D & Fu's Fs & $R_{2}$ & $r$ \\
\hline S. lancifer & COI & $-2,523 *$ & $-14,093^{*}$ & $0.030 *$ & 0.12 \\
& EF1 $\alpha$ & -0.700 & $-4,255^{*}$ & 0.12 & 0.06 \\
S. acuminatum & COI & $-1.542 *$ & $-7.042^{*}$ & $0.065^{*}$ & 0.08 \\
& EF1 $\alpha$ & N.A. & N.A. & N.A. & N.A. \\
\hline
\end{tabular}




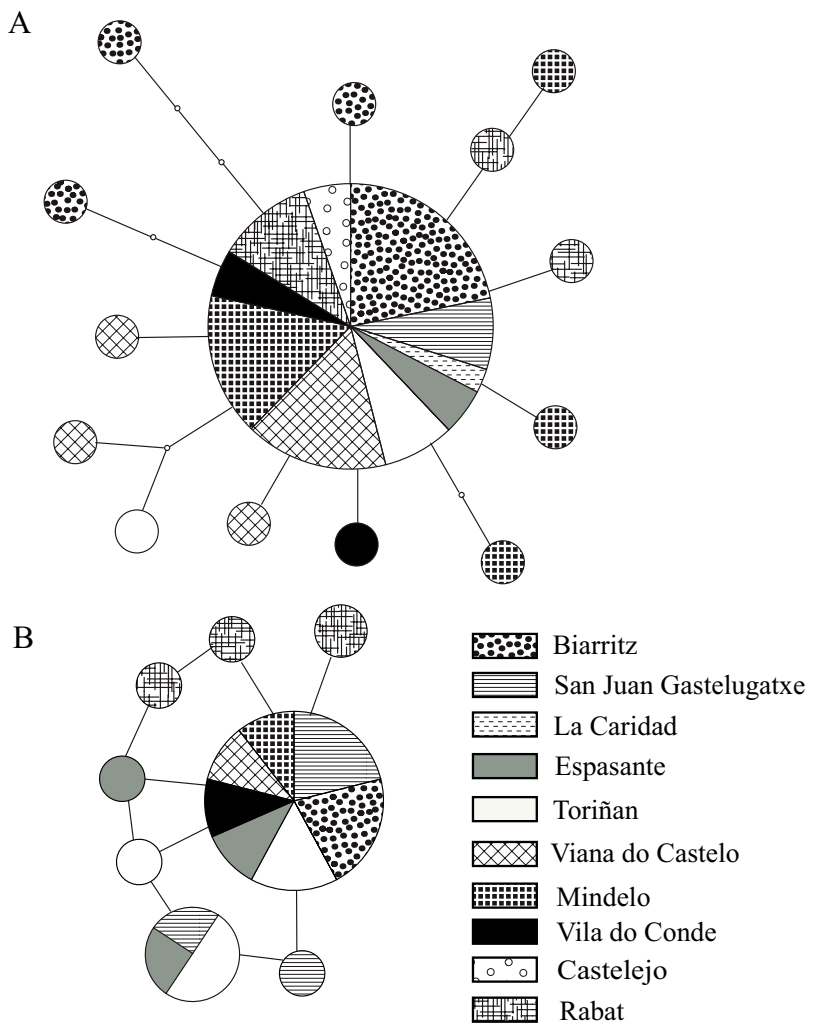

FIG. 2. - A) Mitochondrial (COI) haplotype network of S. lancifer; B) Nuclear $(\mathrm{EF} 1 \alpha)$ haplotype network of $S$. lancifer. Circles are proportional to the number of haplotypes and localities are coded by filling patterns. Each branch connecting haplotypes represents one nucleotide substitution. The smallest open circles represent unobserved haplotypes.

ble 2). For the EF1 $\alpha$ of S. lancifer, Tajima's D and R2 were not significant, which contrasts with significance in Fu's FS, and the Harpending's raggedness index (Table 2).

\section{Population differentiation, isolation by distance and phylogenetic analyses}

For S. lancifer, observed pairwise Fst values between localities were not significantly different from zero (for $P=0.05$ ) (results not shown). In the case of $S$. acuminatum, significant differentiation was found between Mindelo and La Caridad ( $\mathrm{Fst}=0.27, P<0.05$ ).

The spatial Bayesian analysis of population structure failed to detect significant genetic structure for both species and all individuals of each species were grouped in one single cluster. For S. acuminatum, $\log (\mathrm{ml})$ for one cluster equaled -65.3901 , with a probability of 1.0 , whereas for $S$. lancifer, the $\log (\mathrm{ml})$ for one cluster was -134.028 , also with a probability of 1.0.

Results of the isolation by distance test showed no significant correlation between genetic distance and geographic distance ( $S$. acuminatum: $r^{2}=0.0334$, one-sided $P=0.6677 ;$ S. lancifer: $r^{2}=0.192$, one sided $P=0.2906)$. Phylogenetic relations between haplotypes are depicted in Figure 2 for $S$. lancifer and in Figure

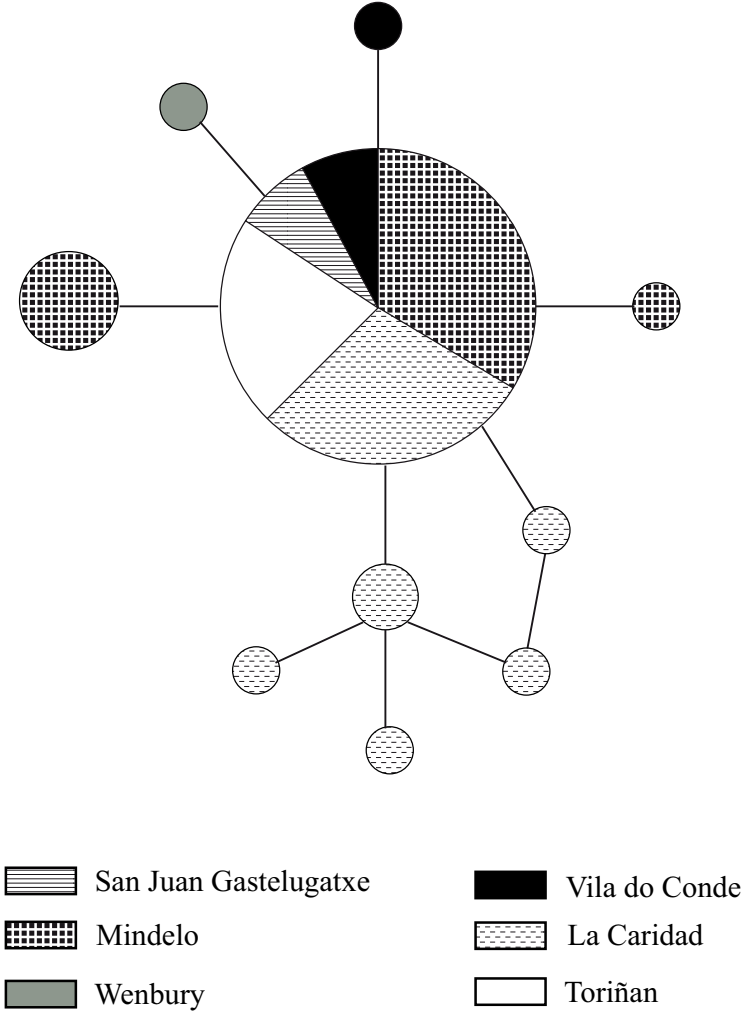

FIG. 3. - Mitochondrial (COI) haplotype network of S. acuminatum. Circles are proportional to the number of haplotypes and localities are coded by filling pattern. Each branch connecting haplotypes represents one nucleotide substitution.

3 for $S$. acuminatum. Star-like phylogenies were retrieved for COI in both species. In the case of $S$. lancifer, a total of 14 haplotypes were observed. Only the central and most common haplotype was shared by all sampled localities. The remaining 13 haplotypes were private to a specific locality (Fig. 2). In the case of $S$. acuminatum, a total of 10 haplotypes were found. Similarly to $S$. lancifer, only the central and most common one was shared by all localities, except Wenbury where only one individual was collected. A star-like phylogeny was also recovered for the EF1 $\alpha$ gene fragment of $S$. lancifer. A total of 8 haplotypes were observed, the most common also being the central one shared by most locations, except Rabat. A second haplotype was shared by locations from northern Spain: Espasante, San Juan de Gastelugatxe and Toriñan. The remaining haplotypes occurred in a single locality. For S. acuminatum no variation was observed for the $\mathrm{EF} 1 \alpha$ gene.

\section{DISCUSSION}

Species with low dispersal abilities have been shown to be prone to maintaining signatures of genetic drift caused by vicariant events (Petit et al. 2003; Pelc et al. 2009). However, in the present study, a general lack of genetic differentiation was observed along the northeast Atlantic coast for two species with direct development: S. lancifer and S. acuminatum. MtDNA 
data analyses revealed one central haplotype that was also the most common along the entire study area, and no relation was found between genetic and geographic distances.

A similar pattern of lack of genetic differentiation in the same geographic region has been observed in other intertidal species, such as Patella rustica Linnaeus, 1758 (Ribeiro et al. 2010), Pollicipes pollicipes (Gmelin, 1789) (Campo et al. 2010) and Nassarius reticulatus (Linnaeus, 1758) (Couceiro et al. 2007), which is not surprising given their high potential for dispersal during the larval stage. In the case of $P$. rustica, it was hypothesized that the prevailing current patterns during the reproductive season could be responsible for the observed genetic homogeneity (Ribeiro et al. 2010). In general, the mean flow on the surface is southward along the Portuguese coast, but seasonal winds can result in both northward and southward flows (Martins et al. 2002). During summer months, currents along Iberia are mainly southward, while during the winter there is a predominant poleward current along the west coasts of Portugal and Spain up to the Armorican shelf, near the French coast (Frouin et al. 1990, Haynes and Barton 1990, Castro et al. 1997).

Long-distance dispersal in species with putative low dispersal abilities, such as Stenosoma, is thought to depend mostly on rafting on floating substrata, particularly on algae where these species are commonly found and on which they possibly feed (Thiel and Gutow 2005, Fraser et al. 2010). The general absence of genetic differentiation throughout the distribution of both $S$. acuminatum and S. lancifer suggests that randomness and regional hydrographic patterns may be promoting high population connectivity, both northwards and southwards. The lack of genetic differentiation is evident for both species (despite the limited number of individuals analyzed), suggesting that the mechanisms and the intensity of processes leading to the high connectivity observed are similar in the two species.

Thiel and Haye (2006) suggested that there may be convergence zones where multiple rafts arrive, thus favouring high levels of gene flow between distant populations and erasing the genetic signatures of founder effects. According to the arguments of Thiel and Haye (2006), to maintain high levels of population connectivity, like the ones observed for S. lancifer and $S$. acuminatum, rafting events must be frequent along the northeast Atlantic coast. Given that for another Stenosoma species (S. nadejda) a significant level of population structure was found in the same region (Xavier et al. 2009), high connectivity through rafting is probably not the only explanation for the patterns observed in the present study.

An alternative explanation for the observed genetic patterns of S. lancifer and S. acuminatum, which is not mutually exclusive with a scenario of high gene flow and high frequency of rafting events, is the occurrence of a recent population bottleneck or even extinction followed by a founder event during re-colonization.
Neutrality tests corroborate this hypothesis, because demographic changes (or selective pressures) were found to be affecting the mtDNA of both species. A scenario of recent demographic expansion (or selective sweep) is in line with the results of a comparative phylogeographic study of intertidal invertebrate assemblages in the North Atlantic by Ilves et al. (2010), who concluded that patterns of genetic variation for most species indicated recent re-colonization following the LGM. However, the latter study, like many others, relied solely on mtDNA so the possible effects of a mitochondrial selective sweep could not be entirely excluded (e.g. Marko 2004; Ilves et al. 2010). Even if mtDNA is considered as a neutral and fast-evolving marker which can give insights on historical demography, the variation it contains does not necessarily reflect the history of a species. Phylogeographic studies may benefit from the inclusion of several markers to unveil the true evolutionary history of species. In the present study, the inclusion of a nuclear marker allows for a better acknowledgment of the possible causes (demography or selection) of the observed patterns of mtDNA genetic variation. It is now widely established that demographic events are expected to affect the whole genome, whereas selection affects specific loci (Andolfatto 2001).

The comparison of the levels of genetic diversity between species and molecular markers prompts for caution in their interpretation and suggest that, for $S$. acuminatum, demographic expansion may not be the only plausible explanation. In fact, $S$. acuminatum shows no genetic variation in $\mathrm{EF} 1 \alpha$, whereas for COI it has a level of genetic diversity higher than that of $S$. lancifer. Although a more detailed analysis is due for a better understanding of the evolutionary processes that shaped the observed genetic structure and diversity of these species, different constraints could be affecting the patterns of genetic variation of S. acuminatum.

Results from the present work contrast with the ones obtained for the congeneric species Stenosoma nade$j d a$. This species was shown to display high levels of genetic structuring, with almost no mtDNA haplotype sharing between sites, from southwest Iberia to the Moroccan coast (Xavier et al. 2009, 2011). These discordant patterns may be attributed to different evolutionary histories and/or biological features (e.g. behaviour, ecology). S. nadejda was recently hypothesized to have survived during the Pleistocene glaciations in multiple areas of southern Iberia and North Africa (Xavier et al. 2011). That, together with a long evolutionary history in this region, could explain its strong population genetic structure. On the other hand, S. acuminatum and $S$. lancifer may have retreated to a single refuge in the north (in Biscay, Brittany or the English Channel), as was proposed for many cold-water taxa (e.g. Kettle et al. 2010) and have a more recent colonization history, which would explain their lower genetic diversity and differentiation compared to those observed for S. nade$j d a$. Yet again, a better understanding of the differences 
in evolutionary history between these congeneric, and partially co-distributed species, requires the study of a larger set of individuals using a larger set of molecular markers.

The patterns of genetic diversity and structure described for S. lancifer and S. acuminatum appear to be best explained by a demographic expansion in their recent past. It is even plausible to suggest that such an event might be related to the climatic changes of the LGM. At least for S. lancifer, this is supported by the observations in the English Channel (Isle of Wight, Brighton) of Bamber (1992), who observed an eastward progression of this species. Based on the present data, the hypothesis that both $S$. acuminatum and $S$. lancifer retracted to a northern glacial refugium, be it in the Gulf of Biarritz, Brittany or the English Channel cannot be discarded. However, glacial refugia may be difficult to pinpoint in the marine environment, since it is known that species with subtidal distributions could have survived during glaciations by migrating to deeper and more stable habitats, thus avoiding the more extreme environmental conditions typical of the intertidal (e.g. Marko 2004, Gómez et al. 2007, Rivadeneira et al. 2011). In fact, while $S$. acuminatum has been reported to occur up to $9 \mathrm{~m}, S$. lancifer occurs between the sublittoral fringes down to $19 \mathrm{~m}$ depth (Saldanha 1974, Anadón 1975).

Hence, more detailed distributional and molecular surveys, with an emphasis on the northernmost distributional limit of S. acuminatum and S. lancifer, are needed to provide more assertive conclusions regarding the location of putative glacial refugia and whether both species are responding similarly to environmental and evolutionary constraints. Additionally, the present results indicate that either in a scenario of high connectivity or in a scenario of a recent range expansion in the northeast Atlantic, after the LGM, the rafting events in this region must be frequent.

\section{ACKNOWLEDGEMENTS}

This work was partly financed by research project PTDC/MAR/104169/2008 from Fundação para a Ciência e a Tecnologia (FCT). R. Xavier and M. Branco have FCT grants with references SFRH/ BD/29370/2006 and SFRH/BPD/40073/2007, respectively. The authors would like to thank Fernando Lima, José Guerra-Garcia, Nuno Queiroz, Pedro Ribeiro, Tânia Rodrigues, Rui Seabra and Lara Sousa for their collaboration during field work. Catarina Rato and David James Harris also provided helpful comments on methodology. Moreover, Martin Thiel and an anonymous referee helped with their useful suggestions on a previous version of this manuscript.

\section{REFERENCES}

Anadón R. 1975. Aportación al conocimiento de la fauna bentónica de la ría de Vigo (NW de España) I. Pignogónidos y crustáceos de Panjón. Invest. Pesq. 39: 199-218.
Andolfatto P. 2001. Adaptive hitchhiking effects on genome variability. Curr. Opin. Genet. Dev. 11: 635-641.

Arrontes J., Anadón R. 1990a. Distribution of intertidal isopods in relation to geographical changes in macroalgal cover in the Bay of Biscay. J. Mar. Biol. Assoc. U. K. 70: 283-293.

Arrontes J., Anadón R. 1990b. Seasonal variation and population dynamics of isopods inhabiting intertidal macroalgae. Sci. Mar. 54: 231-240.

Bamber R. 1992. Eastward progression of the Lusitanian isopod Synisoma lancifer (Dollfus). Porcupine Newsletter. 5: 140.

Campo D., Molares J., Garcia L., Fernandez-Rueda P., GarciaGonzalez C., Garcia-Vazquez E. 2010. Phylogeography of the European stalked barnacle (Pollicipes pollicipes): identification of glacial refugia. Mar. Biol., 157: 147-156.

Castellanos C., Junoy J. 2005. Synisoma albertoi, a new species from the Strait of Gibraltar (southern Spain) with a key to known species of the genus (Crustacea: Isopoda: Idoteidae). $J$. Mar. Biol. Assoc. U. K. 85: 1-6.

Castro C.G., Alvarez-Salgado X. A., Figueiras F.G., Perez F.F., Fraga F. 1997. Transient hydrographic and chemical conditions affecting microplankton populations in the coastal transition zone of the Iberian upwelling system (NW Spain) in September 1986. J. Mar. Res. 55: 321-352.

Clement M., Posada D., Crandall K. 2000. TCS: a computer program to estimate gene genealogies. Mol. Ecol. 9: 1657-1660

Corander J., Waldmann P., Marttinen P., Sillanpää M.J. 2004. BAPS 2: enhanced possibilities for the analysis of genetic population structure. Bioinformatics 20: 2363-2369.

Corander J., Sirén J., Arjas E. 2008. Bayesian Spatial Modelling of Genetic Population Structure. Comp. Stat. 23: 111-129.

Couceiro L., Barreiro R., Ruiz J.M., Sotka E.E. 2007. Genetic isolation by distance among populations of the netted dog whelk Nassarius reticulatus (L.) along the European Atlantic coastline. J. Hered. 98: 603-610.

Coyer J.A., Diekmann O.E., Serrão E.A., Procaccini G., Milchakova N., Pearson G.A., Stam W.T., Olsen J.L. 2004. Population genetics of dwarf eelgrass Zostera noltii throughout its biogeographic range. Mar. Ecol. Prog. Ser. 281: 51-62.

Coyer J.A., Peters A.F., Stam W.T., Olsen J.L. 2003. Post-ice age recolonization and differentiation of Fucus serratus L. (Phaeophyceae; Fucaceae) populations in Northern Europe. Mol. Ecol. 12: 1817-1829.

Excoffier L., Laval G., Schneider S. 2005. Arlequin ver. 3.0: An integrated software package for population genetics data analysis. Evol. Bioinform. Online 1: 47-50.

Flot J.-F. 2010. SEQPHASE: a web tool for interconverting PHASE input/output files and FASTA sequence alignments. Mol. Ecol. Res. 10: 162-166.

Fransen C.H.J.M., De Grave S. 2009. Evolution and radiation of shrimp-like decapods: an overview. In: Martin J.W., Crandall K.A., Felder D.L. (eds.), Decapod Crustacean Phylogenetics. CRC Press, pp. 246-259.

Fraser C.I., Nikula R., Waters J.M. 2010. Oceanic rafting by a coastal community. Proc. R. Soc. Biol. Sci. Ser. B. doi: 10.1098/ rspb.2010.1117

Frouin R., Fuiza A.F., Ambar I., Boyd T.J. 1990. Observations of a poleward surface current off the coasts of Portugal and Spain during the winter. J. Geophys. Res. 95: 679-691.

Fu Y.-X. 1997. Statistical tests of neutrality of mutations against population growth, hitchhiking and background selection. $\mathrm{Ge}$ netics 147: 915-925.

Gómez A., Hugues R.N., Wright P.J., Carvalho G.R., Lunt D.H. 2007. Mitochondrial DNA phylogeography and mating compatibility reveal marked genetic structuring and speciation in the NE Atlantic bryozoan Celleporella hyalina. Mol. Ecol. 16: 2173-2188.

Harpending R.C. 1994. Signature of ancient population growth in a low-resolution mitochondrial DNA mismatch distribution. Hum. Biol. 66: 591-600.

Haynes R., Barton E.D. 1990. A poleward flow along the Atlantic coast of the Iberian Peninsula. J. Geophys. Res. 95: 11425-11441

Hewitt G.M. 1996. Some genetic consequences of ice ages, and their role in divergence and speciation. Biol. J. Linn. Soc. 58: 247-276.

Hewitt G.M. 1999. Post-glacial re-colonization of European biota. Biol. J. Linn. Soc. 68: 87-112. 
Hewitt G.M. 2004. Genetic consequences of climatic oscillations in the Quaternary. Philos. Trans. R. Soc. Lond. B Biol. Sci. 359: 183-195.

Hudson R.R., Kaplan N.L. 1985. Statistical properties of the number of recombination events in the history of a sample of DNA sequences. Genetics 111: 147-164.

Ilves K.L., Huang W., Wares J.P., Hickerson M.J. 2010. Colonization and/or mitochondrial selective sweeps across the North Atlantic intertidal assemblage revealed by multi-taxa approximate Bayesian comput. Mol. Ecol. 19: 4505-4519.

Jensen J.L., Bohonak A.J., Kelley S.T. 2005. Isolation by distance, web service. BMC Genet. 6: 13.

Kettle A.J., Morales-Muñiz A., Roselló-Izquierdo E., Heinrich D., Vøllestad L.A. 2010. Refugia of marine fish in the Northeast Atlantic during the Last Glacial Maximum: concordant assessment from archaeozoology and palaeotemperature reconstructions. Climate of the Past Discussions 6: 1351-1389.

Leach W.E. 1814. Crustaceology, The Edinburgh Encyclopaedia. Blackwood, Edinbourgh. 7: 383-437.

Librado P., Rozas J. 2009. DnaSP v5: A software for comprehensive analysis of DNA polymorphism data. Bioinformatics 25: 1451-1452.

Luttikhuizen P.C., Campos J., van Bleijswijk J., Peijnenburg K.T.C.A., van der Veer H.W. 2008. Phylogeography of the common shrimp, Crangon crangon (L.) across its distribution range. Mol. Phylogenet. Evol. 46: 1015-1030.

Maggs C.A., Castilho R., Foltz D., Henzler C., Jolly M.T., Kelly J., Olson J., Perez K.E., Stam W., Vainola R., Viard F., Wares J. 2008. Evaluating signatures of glacial refugia for North Atlantic benthic marine taxa. Ecology 89: S108-S122.

Marko P.B. 2004. 'What's larvae got to do with it?' Disparate patterns of post-glacial population structure in two benthic marine gastropods with identical dispersal potential. Mol. Ecol. 13: 597-611.

Martins C.S., Hamann M., Fuiza A.F.G. 2002. Surface circulation in the eastern North Atlantic from drifters and altimetry. J. Geophys. Res. 107: 3217.

Ménot G., Bard E., Rostek F., Weijers J.W.H., Hopmans E.C., Schouten S., Damsté J.S.S. 2006. Early reactivation of European rivers during the last deglaciation. Science 313.

Miers E.J. 1881. Revision of the Idoteidae, a family of sessile-eyed Crustacea. J. Linn. Soc. London 16: 1-88.

Miranda L., Thiel M. 2008. Active and passive migration in boring isopods Limnoria spp. (Crustacea, Peracarida) from kelp holdfasts. J. Sea Res. 60: 176-183.

Palero F., Abelló P., Macpherson E., Gristina M., Pascual M. 2008. Phylogeography of the European spiny lobster (Palinurus elephas): Influence of current oceanographical features and historical processes Mol. Phylogenet. Evol. 48: 708-717.

Pelc R.A., Warner R.R., Gaines S.D. 2009. Geographical patterns of genetic structure in marine species with contrasting life histories. J. Biogeogr. 36: 1881-1890.

Pereira S.G., Lima F.P., Queiroz N.C., Ribeiro P.A., Santos A.M. 2006. Biogeographic patterns of intertidal macroinvertebrates and their association with macroalgae distribution along the Portuguese coast. Hydrobiologia 555: 185-192.

Petit R.J., Aguinagalde I., de Beaulieu J.-L., Bittkau C., Brewer S., Cheddadi R., Ennos R., Fineschi S., Grivet D., Lascoux M., Mohanty A., Muller-Starck G., Demesure-Musch B., Palmé A., Martín J.P., Rendell S., Vendramin G.G. 2003. Glacial refugia: hotspots but not melting pots of genetic diversity. Science 300: 1563-1565.

Provan J., Bennett K.D. 2008. Phylogeographic insights into cryptic glacial refugia. Trends Ecol. Evol. 23: 564-571.

Ramos-Onsins S.E., Rozas J. 2002. Statistical properties of new neutrality tests against population growth. Mol. Biol. Evol. 19: 2092-2100.

Ribeiro P.A., Branco M., Hawkins S.J., Santos A.M. 2010. Recent changes in the distribution of a marine gastropod, Patella rustica, across the Iberian Atlantic coast did not result in diminished genetic diversity or increased connectivity. J. Biogeogr. 37: 1782-1796.

Rivadeneira M.M., Thiel M., González E.R., Haye P.A. 2011. An inverse latitudinal gradient of diversity of peracarid crustaceans along the Pacific coast of South America: out of the deep-south. Global Ecol. Biogeogr. 20: 437-448.

Rozas J., Gullaud M., Blandin G., Aguadé M. 2001. DNA variation at the rp49 gene region of Drosophila simulans: evolutionary inferences from an unusual haplotype structure. Genetics 158: 1147-1155.

Saldanha L. 1974. Estudo do povoamento dos horizontes superiores da rocha litoral da costa da Arrábida (Portugal). Arquivos do Museu de Bocage 5: 1-382.

Stephens M., Donnelly P. 2003. A comparison of bayesian methods for haplotype reconstruction from population genotype data. Am. J. Hum. Genet. 73: 1162-1169.

Stephens M., Scheet P. 2005. Accounting for decay of linkage disequilibrium in haplotype inference and missing-data imputation. Am. J. Hum. Genet. 76: 449-462.

Stephens M., Smith N.J., Donnelly P. 2001. A New Statistical Method for Haplotype Reconstruction from population data. Am. J. Hum. Genet. 68: 978-989.

Taberlet P., Fumagalli L., Wust-Saucy A.-G., Cosson J.-F. 1998. Comparative phylogeography and post glacial colonization routes in Europe. Mol. Ecol. 7: 453-464.

Tajima F. 1989a. The effect of change in population size on DNA polymorphism. Genetics 123: 597-601.

Tajima F. 1989b. Statistical method for testing the neutral mutation hypothesis by DNA polymorphism. Genetics 123: 585-595.

Thiel M., Gutow L. 2005. The ecology of rafting in the marine environment. II. The rafting organisms and community. Oceanogr. Mar. Biol. 43: 279-418.

Thiel M., Haye P. A. 2006. The ecology of rafting in the marine environment. III. Biogeographical and evolutionary consequences. Oceanog. Mar. Biol. 44: 323-429.

Wares J.P., Cunningham C.W. 2001. Phylogeography and historical ecology of the North Atlantic intertidal. Evolution 55: 2455-2469.

Xavier R., Santos A.M., Lima F.P., Branco M. 2009. Invasion or invisibility: using genetic and distributional data to investigate the alien or indigenous status of the Atlantic populations of the peracarid isopod, Stenosoma nadejda (Rezig 1989). Mol. Ecol. 18: 3283-3290.

Xavier R., Zenboudji S., Harris D.J., Lima F.P., Santos A.M., Branco M. In press. Phylogeography of the marine isopod Stenosoma nadejda (Rezig, 1989) in North African Atlantic and western Mediterranean coasts reveals complex differentiation patterns and a new species. Biol. J. Linn. Soc.

Zink R.M. 2002. Methods in comparative phylogeography, and their application to studying evolution in the North American aridlands. Integr. Comp. Biol. 42: 953-959.

Scient. ed.: R. Anadón.

Received March 2, 2011. Accepted June 23, 2011.

Published online November 29, 2011. 